\title{
Purification and Properties of Coproporphyrinogenase
}

\author{
By A. M. Del C. BATLLE,* A. BENSON ANd C. RIMINGTON \\ Department of Chemical Pathology, University College Hospital Medical School, London, W.C. 1
}

\author{
(Received 6 May 1965)
}

\begin{abstract}
1. Coproporphyrinogenase has been prepared from rat-liver mitochondria and its properties have been studied. The isoelectric point was found to be around pH5.0 and the molecular weight to be $80000 \pm 8000$. The $\mathrm{pH}$ optimum of the enzymic reaction was 7.4 and the apparent $K_{m}$ was of the order $0.03 \mathrm{~mm}$. The enzyme was destroyed by boiling and irreversible inactivation occurred below pH3.5. It could be stored at $-10^{\circ}$ without loss of activity. The enzyme acts specifically on coproporphyrinogen III and does not form protoporphyrinogen from trans-2,4-diacrylicdeuteroporphyrin or its porphyrinogen. It was unaffected by prolonged dialysis and no cofactor requirement could be demonstrated. 2 . Column chromatography of a partially purified enzyme preparation on Sephadex G-200 was found to be an improved method of purification, which gave a coproporphyrinogenase 58-fold purified. The purified enzyme was studied electrophoretically but no evidence was obtained to suggest that more than one enzyme was involved in the reaction. 3. The action was studied of various compounds added to the system. The presence of monothiol groups in the enzyme system was indicated, whereas vicinal dithiol groups were not involved in the reaction. Metalchelating agents did not inhibit the reaction and no requirement for the presence of any essential metal has been found. All attempts to demonstrate the presence of a prosthetic group, in particular flavines, failed. Neither pyridoxal phosphate nor ATP was involved in the reaction, nor was a mitochondrial electron-transport chain required for the activity of the enzyme. Some circumstantial evidence was obtained to suggest that cis-2,4-diacrylicdeuteroporphyrin is an intermediate in the reaction.
\end{abstract}

The penultimate step of haem biosynthesis, namely the conversion of coproporphyrinogen III (CPG III) into protoporphyrin IX involves the oxidative decarboxylation of two propionic acid side chains to vinyl groups (positions 2 and 4) and the oxidative removal of six hydrogen atoms from the protoporphyrinogen nucleus. Protoporphyrinogen is formed as an intermediate (Sano \& Granick, 1961). Whether the change of propionyl to vinyl takes place in one or more steps is not known yet. The enzyme responsible for this transformation, coproporphyrinogen-(acceptor) oxidoreductase (decarboxylating), will be referred to shortly as 'coproporphyrinogenase'. It appears to be a particulate enzyme but has been obtained in soluble form from Euglena and chicken erythrocytes (Granick \& Mauzerall, 1958) and liver mitochondria (Sano, 1958; Sano \& Granick, 1961 ; Porra \& Falk, 1961; Rimington \& Tooth, 1961) and has been partly purified by Sano \& Granick (1961).

The enzyme reaction is completely inhibited by

* Present address: Cátedra de Química Biológica, Faculdad de Ciencias Exactas, Universidad de Buenos Aires, Buenos Aires, Argentina. anaerobic conditions (Falk, Dresel \& Rimington, 1953). Several attempts have been made unsuccessfully to achieve the conversion under anaerobic conditions in the presence of various electron acceptors (Sano \& Granick, 1961 ; Porra \& Falk, 1964). The nature of the primary electron acceptor is still not known and no substitute for molecular oxygen as oxidant has been found. The coproporphyrinogenase preparation of Sano \& Granick (1961) and Granick \& Levere (1964) contained some flavine, but no flavine-containing prosthetic group was characterized.

This paper describes further purification of the coproporphyrinogenase from rat-liver mitochondria, some properties of the enzyme, and some studies on the mechanism of the enzymic oxidative decarboxylation involved in this unusual transformation.

\section{EXPERIMENTAL Materials}

Coproporphyrin III. This was derived from Corynebacterium diphtheriae (Gray \& Holt, 1948). A stock solution, approx. $0.5 \mathrm{~mm}$ in $0.01 \mathrm{M}-\mathrm{KOH}$, was stored at $4^{\circ}$. 
Coproporphyrinogen III. This was prepared, following Mauzerall \& Granick (1958), as follows. The porphyrin solution, in a large stoppered test tube cooled in an ice bath, was treated with freshly ground $3 \%(w / w)$ sodium amalgam (about lg./ml.). This and subsequent steps were carried out in a dimly lit room and, whenever possible, under a dark hood through which a constant stream of $\mathrm{N}_{2}$ was passed. The tube was flushed with $\mathrm{N}_{2}$, stoppered and shaken vigorously. After a few minutes the fluorescence disappeared as the porphyrin was reduced to the colourless porphyrinogen. The solution was rapidly filtered by suction through a fine sintered-glass disk into a tube containing $2 \mathrm{M}$-potassium thioglycollate, to give a final concentration of $0.05 \mathrm{M}$ (unless otherwise stated), and titrated to $\mathrm{pH} 7 \cdot 3$ 7.4 with $40 \%(w / v) \mathrm{H}_{3} \mathrm{PO}_{4}$. The resulting solution was used immediately. The yield of CPG III*, determined after re-oxidation to coproporphyrin III, under different conditions was $80-90 \%$.

trans-2,4-Diacrylicdeuteroporphyrin. This was synthesized by a modification (A. M. del C. Batlle \& C. Rimington, unpublished work) of the procedure of Sparatore \& Mauzerall (1960) and reduced to the porphyrinogen according to Sano \& Granick (1961).

Other compounds. Starch gel for electrophoresis was obtained from Connaught Medical Laboratories, Toronto, Canada. Sephadex is produced by Pharmacia, Uppsala, Sweden, and the different types were obtained from the London agents, Pharmacia (G.B.) Ltd., Sinclair House, The Avenue, London, W. 13. Calcium phosphate gel was prepared according to Keilin \& Hartree (1951). Hydrochloric acid solutions were made from AnalaR conc. $\mathrm{HCl}(11.6 \mathrm{~N}$ or $42 \cdot 3 \%, w / v$; British Drug Houses Ltd.) and are recorded in terms of weight of acid/100 ml. All other reagents used were of A.R. grade.

\section{Methods}

Enzyme preparations. The source of the CPGase was rat-liver mitochondria. The few occasions when rat-heart mitochondria, chicken erythrocyte haemolysate or human blood were used are specified. All manipulations were carried out at $4^{\circ}$ unless otherwise indicated.

Mitochondria were prepared by the method of Hogeboom (1955) and washed once, the medium for isolation and washing being $0.25 \mathrm{M}$-sucrose. The packed mitochondria were kept at $-10^{\circ}$ until used, in general on the same or the following day.

Acetone-dried powder of mitochondria was prepared as follows. The packed mitochondria were suspended in deionized water ( $a$ volume equal to half the weight of liver used). This suspension was shaken with 12 vol. of ice-cold acetone (previously chilled to $-10^{\circ}$ ), and the mixture left to stand for $30 \mathrm{~min}$. at $-10^{\circ}$. The precipitate was filtered with suction and, after washing three times with chilled acetone and three times with chilled ether, the powder was stored in vacuo at $-10^{\circ}$ over $\mathrm{NaOH}$.

Rat-heart mitochondria were prepared in the same way as rat-liver mitochondria. Chicken haemolysates were prepared as described by Dresel \& Falk (1954). Human blood was collected and used as described by Cornford (1964).

*Abbreviations: CPG III, coproporphyrinogen III; CPGase, coproporphyrinogenase.
Incubation conditions. Experiments were carried out with different preparations as enzyme source: $(a)$ packed mitochondria suspended in 0.1 M-tris-HCl buffer, $\mathrm{pH} 7.4$ (giving a suspension containing 36-38 mg. of protein $/ \mathrm{ml}$.); (b) acetone-dried powder of mitochondria suspended in 0.1 M-tris-HCl buffer, pH7.4 (34-36 mg. of protein/ml.); (c) partially purified enzyme, obtained as described in the Results section, in 0.01 M-tris-HCl buffer, pH7.4 (approx. $4 \mathrm{mg}$. of protein/ml.); (d) purified enzyme, obtained as described in the Results section, in 0.05 M-tris-HCl buffer, pH 7.4 (2 mg. of protein/ml.).

Incubations were carried out aerobically in $10 \mathrm{ml}$. conical flasks for $2 \mathrm{hr}$. at $38^{\circ}$ with mechanical shaking at about 90-100 oscillations/min. The standard system used was: $1 \mathrm{ml}$. of enzyme solution, or suspension, in 0.01 M-tris- $\mathrm{HCl}$

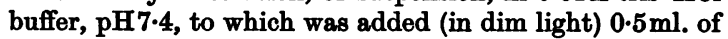
freshly prepared CPG III (approx. $0.15 \mathrm{~mm}$ ) and sufficient $0.1 \mathrm{M}$-tris-HCl buffer, $\mathrm{pH} 7.4$, to make a final volume of $2 \mathrm{ml}$. The concentration of CPG III used was determined in every experiment.

Enzyme unit. CPGase unit was defined as the amount of enzyme that catalyses the formation of $1 \mu$ mole of protoporphyrin IX/min. from CPG III, under standard conditions, the specific activity being the units of CPGase/mg. of protein.

Fractionation and determination of porphyrins. After incubation, $0.33 \mathrm{ml}$. of conc. $\mathrm{HCl}$ was added to each flask to precipitate the protein; the mixture was then exposed to light and air for 20-30 min. at room temperature to convert any porphyrinogens into porphyrins. The precipitated protein was removed by filtration through a Whatman no. 1 folded filter paper, the precipitate being washed well with $3 \times 3 \mathrm{ml}$. and then $2 \times 1.5 \mathrm{ml}$. of $5 \% \mathrm{HCl}$; filtrate and washings were combined.

The acid solution was promptly neutralized to $\mathrm{pH3.4}$ 3.5 with approx. $5 \mathrm{ml}$. of saturated sodium acetate (narrowrange indicator paper) and extracted to completion into ether (usually $1 \times 15 \mathrm{ml}$. and $2 \times 10 \mathrm{ml}$.). The ether phase was washed with $1 \times 5 \mathrm{ml}$. of $3 \%(\mathrm{w} / \mathrm{v})$ sodium acetate and $1 \times 5 \mathrm{ml}$. of water. The aqueous washings were extracted two or three times with ether, and finally all the ether extractions were combined.

From the ether, coproporphyrin was extracted by shaking three times with $6 \mathrm{ml}$. of $0.36 \% \mathrm{HCl}$ and the solution diluted to $20 \mathrm{ml}$. with the same acid. Protoporphyrin was then extracted with $3 \times 3 \mathrm{ml}$. of $5 \% \mathrm{HCl}$ and diluted to $10 \mathrm{ml}$. with the same acid.

The concentrations of porphyrin were calculated by using the correction formula of Rimington \& Sveinsson (1950). Extinction of each extract was read at $380 \mathrm{~m} \mu$, $430 \mathrm{~m} \mu$ and at the Soret maximum $\left(E_{\max }\right)$ with $1 \mathrm{~cm}$. cells and a Unicam SP.500 spectrophotometer.

Porphyrins were further characterized by paper chromatography by using the lutidine method (Eriksen, 1958) and, after esterification, by the dioxan method (Falk \& Benson, 1953).

In experiments with trans-2,4-diacrylicdeuteroporphyrin, fractionation and determination of the porphyrins formed followed the procedure of Sano \& Granick (1961).

An attempt was made to simplify further the extraction and determination of coproporphyrin and protoporphyrin by using the procedure described by Porra \& Falk (1964) and called 'the simultaneous equation' method, in which coproporphyrin and protoporphyrin are estimated together 
in $5 \% \mathrm{HCl}$; but we have found constants for $E_{\mathrm{mx}}$ of coproporphyrin III at $401.5 \mathrm{~m} \mu$ and $408 \mathrm{~m} \mu$, in $5 \% \mathrm{HCl}$, different from those reported by the authors, our findings being $E_{401.5}^{m i x} 425$ and $E_{408}^{m x} 170$. Also the method was found to be inaccurate when the proportion of protoporphyrin IX was lower than $20 \%$ of the total.

Chromatography on Sephadex columns. The partially purified preparation was passed through Sephadex columns of different types, which had been prepared as follows. A weighed amount of the dry Sephadex powder was suspended in excess of the buffer solution to be used as medium and allowed to swell for the time required by each type. To avoid trapping of air bubbles in the column, the suspensions were deaerated by suction. Each column was packed in a vertical glass tube in which was fused a sinteredglass disk (medium porosity) to support the gel. A layer of glass beads (approx. 0.8-1 cm. depth) prevented blockage of the disk by gel particles. After half of the tube was filled with the buffer, portions of swollen Sephadex were poured into it. When a layer a few centimetres thick had formed, the tap was opened to allow an even outflow. The remainder of the suspension was added and, after the column was evenly packed, it was left running for $24 \mathrm{hr}$. with buffer added at the same rate as the effluent drained away. When the packing was completed, the upper surface of the gel was covered with a well-fitting filter-paper disk (Whatman no. 1).

Before operations with the enzyme preparation were started, homogeneity of the column was checked by filtering cytochrome $c$ through the bed. Different types of Sephadex gave different flow rates.

Estimation of molecular weight. Estimations for different enzyme preparations by Sephadex-gel filtration were studied according to the method of Andrews (1964). Sephadex G-75 and G-100 columns for estimation of molecular weight were calibrated with cytochrome $c$, sucrose, glucagon, oxalbumin, $\beta$-globulin, thyroglobulin and serum albumin. Some fractions obtained from Sephadex columns were concentrated by pressure filtration through viscose tubing as described by Wildy, Nizet \& Benson (1961). Protein content was determined by the Folin-Ciocalteu micro-method as described by Lowry, Rosebrough, Farr \& Randall (1951); calibration was with bovine serum albumin and standard casein.

Starch-gel electrophoresis. The technique employed was based on the methods described by Bodman (1960). A preliminary survey was made to find the most suitable $\mathrm{pH}$ for running the different samples obtained from Sephadex columns.

At $\mathrm{pH}$ values greater than 7 the partially purified enzyme is resolved into several bands, so a borate buffer was adopted, with the following composition: boric acid, $0.3 \mathrm{~mole} / \mathrm{l}$., and $\mathrm{NaOH}, 0.05 \mathrm{~mole} / \mathrm{l}$., $\mathrm{pH} 8 \cdot 0$, for the electrode chamber and filter-paper bridges; boric acid, $0.023 \mathrm{~mole} / \mathrm{l}$., and $\mathrm{NaOH}, 0.0092 \mathrm{~mole} / 1$., $\mathrm{pH} 8 \cdot 0$, for gel preparation.

\section{RESULTS}

Extraction and partial purification of the enzyme. Partially purified enzyme preparations were obtained by the procedure of Sano \& Granick (1961) modified as described below. All reagents were chilled to the temperature of the cold room.
Extraction of the enzyme from acetone-dried powder of mitochondria can be accomplished in two ways.

(a) In a Potter glass homogenizer, approx. $2 \mathrm{~g}$. of acetone-dried powder of mitochondria was homogenized with $210 \mathrm{ml}$. of a mixture containing $180 \mathrm{ml}$. of 0.1 M-tris-hydrochloric acid buffer, $\mathrm{pH} 9 \cdot 0,18 \mathrm{ml}$. of $2 \mathrm{M}$-potassium thioglycollate and $12 \mathrm{ml}$. of $5 \%$ hydrochloric acid (to give final pH 8.8-9.0). The suspension was stirred gently either in air or under nitrogen (the gas phase proved to be immaterial) for $24 \mathrm{hr}$. at $0^{\circ}$, and then centrifuged at $20000 \mathrm{~g}$ for $45 \mathrm{~min}$. Over $80 \%$ of the activity was in the supernatant fluid.

(b) About 2g. of the acetone-dried powder of mitochondria was treated for $5 \mathrm{~min}$. with $50 \mathrm{ml}$. of the same mixture as in (a) in a $100 \mathrm{ml}$. beaker submerged in an ice bath, in an MSE ultrasonic disintegrator with a titanium probe $0.75 \mathrm{in}$. in diameter, operating at $20 \mathrm{kcyc}$. $/ \mathrm{sec}$. and $1 \cdot 5 \mathrm{~A}$. The suspension was centrifuged at $15000 \mathrm{~g}$ for $10 \mathrm{~min}$.; two further extractions $(50 \mathrm{ml}$. each) were required to extract all CPGase activity from the residue. The combined supernatants were centrifuged at $20000 \mathrm{~g}$ for 45 $50 \mathrm{~min}$. The specific activity of extracts prepared by (a) or (b) was the same (Table 1).

The supernatant obtained by either procedure (a) or (b) was adjusted to $\mathrm{pH} 7.4$ with $5 \%$ hydrochloric acid, and neutralized saturated ammonium sulphate was added to $55 \%$ saturation. A nomogram giving the amount required to pass from any percentage saturation to any other was used (Dixon, 1953).

After lhr. the material was centrifuged at $11750 \mathrm{~g}$ for $10 \mathrm{~min}$. The sediment had very little activity and was discarded. The supernatant solution was brought to $75 \%$ saturation with ammonium sulphate and, after $1 \mathrm{hr}$., centrifuged at $11750 \mathrm{~g}$ for $10 \mathrm{~min}$. The precipitate was dissolved in $50 \mathrm{ml}$. of $0.01 \mathrm{M}$-tris-hydrochloric acid buffer, $\mathrm{pH} 7 \cdot 4$. To this solution was added $10 \mathrm{ml}$. of calcium phosphate gel (containing $40 \mathrm{mg}$. dry wt. of $\mathrm{gel} / \mathrm{ml}$.); after stirring for $10 \mathrm{~min}$. the gel was removed by centrifugation at $1060 \mathrm{~g}$ for $10 \mathrm{~min}$., and the gel was discarded.

The protein in the supernatant solution was precipitated by dialysis against two changes (100 vol. of dialysing medium) of saturated ammonium sulphate (pH 7.0-7.4) for $20 \mathrm{hr}$. The precipitate was centrifuged at $11750 \mathrm{~g}$ for $10 \mathrm{~min}$., suspended in a small volume of $0.01 \mathrm{M}$-tris-hydrochloric acid buffer, $\mathrm{pH} 7 \cdot 4$, and dialysed against two changes of the same buffer, $\mathrm{pH} \mathrm{7 \cdot 4}$, for $24 \mathrm{hr}$. The solution obtained was then centrifuged for $30 \mathrm{~min}$. at $11750 \mathrm{~g}$, yielding a clear pale-yellow solution with green-yellowish fluorescence; the purification was 18-fold. This preparation was called 'partially purified enzyme'.

Properties of coproporphyrinogenase. Studies of 
Table 1. Purification of coproporphyrinogenase from rat-liver mitochondria

Incubation conditions were as described in the Methods section.

\begin{tabular}{|c|c|c|c|c|c|}
\hline Materials* & $\begin{array}{c}\text { Total } \\
\text { protein } \dagger \\
\text { (mg.) }\end{array}$ & $\begin{array}{l}10^{3} \times \\
\text { Total } \\
\text { units }\end{array}$ & $\begin{array}{l}\text { Yield } \\
(\%)\end{array}$ & $\begin{array}{c}10^{5} \times \\
\text { Specific } \\
\text { activity }\end{array}$ & $\begin{array}{c}\text { Purifica- } \\
\text { tion }\end{array}$ \\
\hline genate & 5000 & $10 \cdot 3$ & 100 & $0 \cdot 206$ & 1 \\
\hline itochondria & 2040 & $8 \cdot 3$ & 81 & 0.407 & 2 \\
\hline dried powder & 2040 & $8 \cdot 4$ & 89 & 0.412 & 2 \\
\hline & 734 & $4 \cdot 3$ & 42 & 0.586 & 2.8 \\
\hline & 721 & $4 \cdot 2$ & 41 & 0.583 & $\mathbf{2 \cdot 8}$ \\
\hline $\left.\mathrm{NH}_{4}\right)_{2} \mathrm{SO}_{4}$ fraction & 138 & $\mathbf{3} \cdot \mathbf{3}$ & 32 & $2 \cdot 391$ & $11 \cdot 2$ \\
\hline ter calcium phosphate gel treatment & 104 & $3 \cdot 2$ & 31 & 3.077 & $14 \cdot 9$ \\
\hline cipitate after gel treatment & 24 & 0.9 & $8 \cdot 6$ & $\mathbf{3} \cdot 750$ & $18 \cdot 2$ \\
\hline
\end{tabular}

Rat-liver homogenate

Packed liver mitochondria

Whole acetone-dried powder

Acetone-dried powder supernatantf

(a)

(b)

$55-75 \%$ satd. $\left(\mathrm{NH}_{4}\right)_{2} \mathrm{SO}_{4}$ fraction

Supernatant after calcium phosphate gel treatment

$\left(\mathrm{NH}_{4}\right)_{2} \mathrm{SO}_{4}$ precipitate after gel treatment

* Dialysed before protein content and activity were determined.

$\uparrow$ Determined by the method of Lowry et al. (1951).

$\ddagger$ Obtained by procedure (a) or procedure (b) as described in the Results section.

porphyrin formation increased linearly with time up to $\mathrm{lhr}$. Formation was also linear with increasing substrate concentration up to $0.04 \mathrm{mM}$.

Under the aerobic conditions required by this enzyme there was continual autoxidation of the substrate despite the presence of potassium thioglycollate, and this made it difficult to carry out accurate kinetic studies, but an estimation of the apparent $K_{m}$ gave a value $0.03 \mathrm{~mm}$. Ascorbic acid ( $5 \mathrm{mM}$ ) had the same effect as potassium thioglycollate in preventing autoxidation of CPG III but potassium thioglycollate was always used.

Heating the system above $80^{\circ}$ for $5 \mathrm{~min}$., or boiling it, completely destroyed its activity. It was quite stable for several months in solution in $0.01 \mathrm{M}$ -

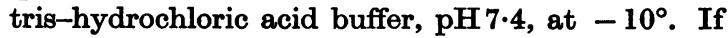
kept at $4^{\circ}$, a very slow fall in enzymic activity occurred.

Dialysis of the enzyme for 48 and $96 \mathrm{hr}$. against four and six changes of $(a) 0.01 \mathrm{M}$-tris-hydrochloric acid buffer, $\mathrm{pH} 7 \cdot 4$, or (b) $0.01 \mathrm{M}$-sodium phosphate buffer, $\mathrm{pH} 7 \cdot 4$, did not affect the activity of the system.

It has been shown by many authors that CPGase has a high degree of specificity. It does not utilize coproporphyrin I or coproporphyrinogen I, coproporphyrin III, coproporphyrin II, coproporphyrinogen II, uroporphyrinogen III, mesoporphyrin IX or mesoporphyrinogen IX (Mauzerall \& Granick, 1958; Sano \& Granick, 1961), nor haematoporphyrin, 2,4-diacetyldeuteroporphyrin IX or their corresponding porphyrinogens (Bogorad, 1960; Bogorad \& Marks, 1960). It also fails to utilize trans-2,4-diacrylicdeuteroporphyrin IX or its porphyrinogen, as shown by Sano \& Granick (1961) and confirmed in this Laboratory. Porra \& Falk (1964) claim, however, that CPGase possesses a 
wider range of specificity than was previously believed, as they have found that coproporphyrinogen IV and 4-propionicdeuteroporphyrinogen are also transformed by ox-liver extract. It has been postulated that the oxidative decarboxylation of coproporphyrinogen III to protoporphyrinogen IX may proceed via the acrylic acid (Rimington \& Tooth, 1961; Sano \& Granick, 1961). As it was found that the trans isomer was not decarboxylated to protoporphyrin it might still be possible that the real intermediate could be the cis isomer, but until now several attempts to synthesize the compound have met with no success (A. M. del C. Batlle \& C. Rimington, unpublished work).

\section{Possible presence of prosthetic groups}

The possible presence in the enzyme system of some flavine, or haem groups, SH residues or metals was investigated.

Examination for lipoic acid. CPGase was treated by the procedure of Seaman \& Naschke (1955) for the removal of thioctic acid from enzymes. The activity was tested of the alumina-treated CPGase, alone or after addition of the extract or of lipoic acid, but no difference was found between the initial and alumina-treated enzyme preparations, and addition of either the extract or of lipoic acid decreased this activity.

Addition of lipoic acid at different concentrations was tested on: (i) partially purified enzyme; (ii) chicken haemolysates; (iii) human blood; (iv) ratheart mitochondria. Results revealed no increase of the activity in the first two systems and no activity at all in the other two, which do not normally show CPGase activity. At concentrations over $0.01 \mathrm{~m}$, lipoic acid inhibited CPGase activity.

Examination for flavine. The absorption spectrum of every partially purified preparation was measured and two clear peaks were found, one at $275 \mathrm{~m} \mu$ and the other at $412 \mathrm{~m} \mu$. The preparations had pale-yellow colour and greenish-yellow fluorescence, which with the spectral-absorption properties suggested the possible presence of some prosthetic groups such as flavine and haem. Following the work of Morton (1961) and Morton, Armstrong \& Appleby (1961), partially purified enzyme was treated at $\mathrm{pH} 4$ in an attempt to obtain a flavinefree enzyme. No change in activity was obtained with different preparations so treated. Moreover, the addition of FMN or FAD at different concentrations to these systems had no effect on the activity. Partially purified enzyme was heated at $100^{\circ}$ for $10 \mathrm{~min}$. The protein precipitate was removed by filtration and the filtrate tested for activity. It had no CPGase activity nor did it increase that of partially purified enzyme or preparations obtained after treatment at $\mathrm{pH} 4 \cdot 0$. Thus a flavine group could neither be isolated nor revealed, but it is not impossible that flavine could be either very tightly bound to the protein, or its spectrum 'masked' by other components, making its recognition very difficult. Attempts to identify other possible prosthetic groups were performed. The presence of a haem group was rendered unlikely on the basis of negative haemochromogen tests.

\section{Further purification of the enzyme}

No substantial further purification of the partially purified enzyme was obtained by precipitation with ammonium sulphate or by chromatography on DEAE-Sephadex. The use of Sephadex G-50, however, doubled the specific activity and by using other types of Sephadex with higher resolving power further substantial purification was achieved with elimination of inactive proteins. The total protein recovery from Sephadex columns was always over $90 \%$. When columns were run at room temperature, a sample of the partially purified enzyme preparation used was kept at the same temperature for the duration of the run to compare the specific activities of the initial and final products. Protein content, spectral absorption at $412 \mathrm{~m} \mu$ and specific activity were determined in each fraction eluted from the columns.

With Sephadex G-75 and G-100, still better resolution was obtained and specific activities were 2.3 and 3 times respectively that of the partially purified enzyme preparation. Ultimately Sephadex G-200, the type of Sephadex with the highest resolution capacity, was used and after two runs on the material, a purified enzyme preparation was obtained which was 3.25 times as active as the initial partially purified preparation, that is to say, overall CPGase purification was about 58-fold.

Fig. 2 depicts such a fractionation on Sephadex G-200. Four main protein peaks and three coloured peaks were obtained. The CPGase activity was associated almost entirely with the third protein band (colourless and non-fluorescent) and was not related to the main coloured protein band. The specific activity of the whole material comprising the active band was three times as high as that of the partially purified enzyme.

Each of the bands was concentrated to $1 \mathrm{ml}$. by pressure filtration and studied electrophoretically (Fig. 3). Band number 3, exhibiting CPGase activity, was rechromatographed on Sephadex G-200, yielding a main band which had a specific activity 3.25 times that of the original partially purified enzyme. The 'purified enzyme' was run once more on Sephadex G-200 and produced only one protein band, which was concentrated to $1 \mathrm{ml}$.; it had unchanged specific activity and similar electrophoretic behaviour. This purified material 


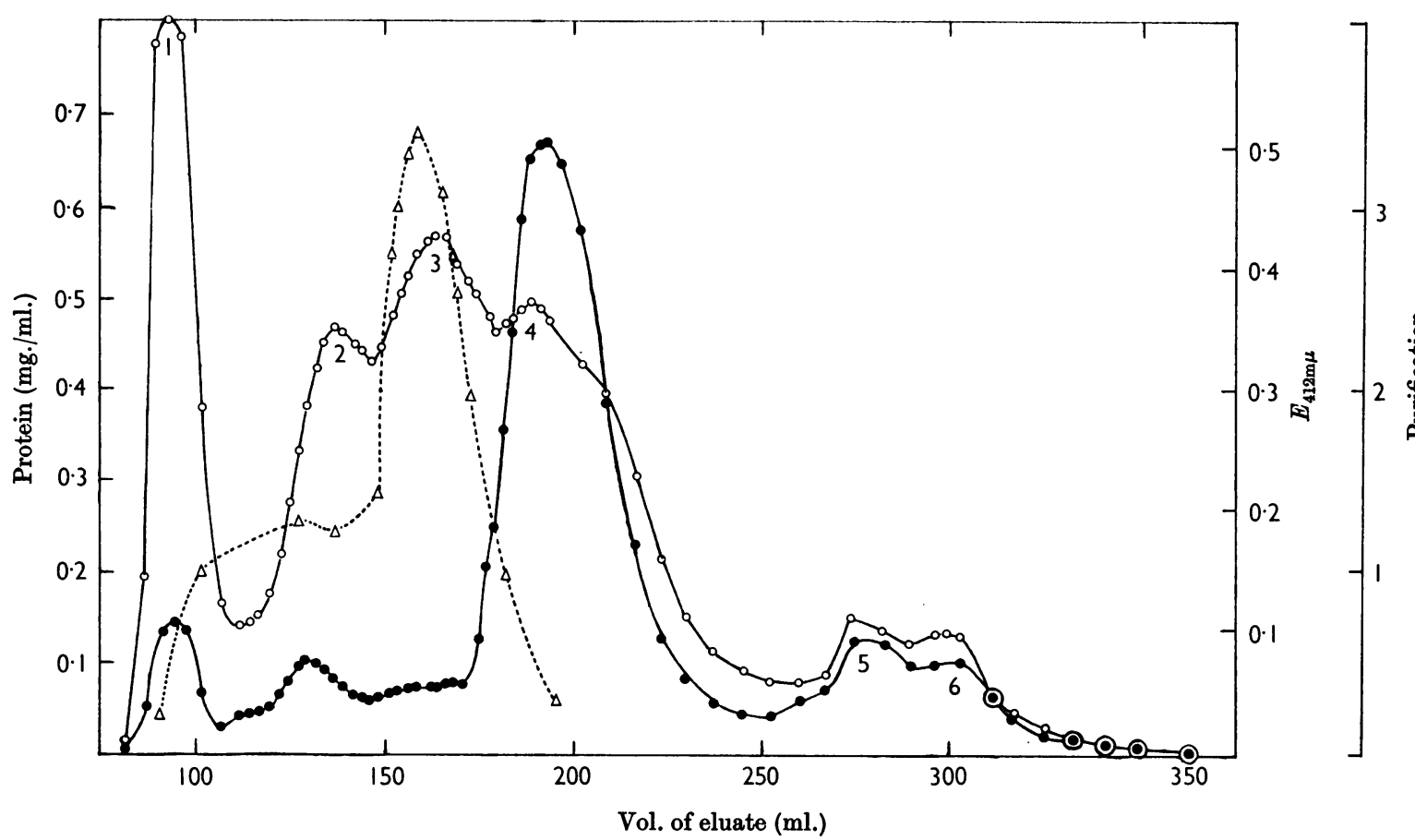

Fig. 2. Chromatographic behaviour of partially purified enzyme on Sephadex G-200. Enzyme preparation (4 ml.; $80 \mathrm{mg}$. of protein) was applied to Sephadex G-200 column $(2.4 \mathrm{~cm} . \times 54 \mathrm{~cm}$.) in $0.05 \mathrm{M}-$ tris-HCl buffer, $\mathrm{pH} 7 \cdot 4$, containing $0.1 \mathrm{M}-\mathrm{KCl}$, and eluted with the same buffer at a flow rate of $0.25 \mathrm{ml} . / \mathrm{min}$. at room temperature. CPGase specific aetivity was determined under standard conditions and is represented in terms of purification, that of partially purified enzyme being taken as 1 . $O$, Protein (mg./ml.); $\Theta_{,} E_{412 \mathrm{~m} \mu} ; \Delta$, degree of purification calculated from increase in specific activity relative to the starting material.

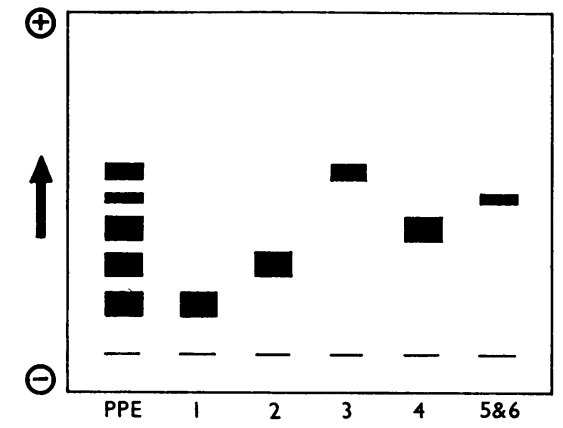

Fig. 3. Electrophoretic behaviour of partially purified enzyme (PPE) and the different bands obtained from Sephadex G-200 columns (Fig. 2). Borate buffer, pH8・0. A current of $35 \mathrm{~mA}$ was passed for $4 \mathrm{hr}$. at room temperature.

was also run on Sephadex G-100, to estimate the molecular weight of the enzymic protein according to the method of Andrews (1964); a value of 80000 $\pm 10 \%$ was obtained. Previous determinations with materials not so purified gave values ranging from 70000 to 90000 .

\section{Effect of various substances on coproporphyrinogenase}

Experiments carried out with different enzyme preparations afforded essentially similar results and, unless otherwise indicated, those obtained with the purified enzyme are shown in Table 2. Reagents were tested with and without addition of potassium thioglycollate to the system with generally similar result. Table 2 shows the final concentration of additives to the reaction mixture.

Arsenite, mono- and di-thols, and various oxidizing agents (Table 2, groups $A$ and $B$ ). A wide range of arsenite concentrations was studied and, in agreement with other authors, it was found that low concentrations did not inhibit CPGase activity. Appreciable inhibition is, however, produced at $0.04 \mathrm{M}$ (Table 2, group A).

It is known that combination with vicinal dithiol groups occurs at much lower concentrations 
Table 2. Effect of various substances on coproporphyrinogenase

Incubation conditions were as described in the Methods section. The activity of the system in the presence of other reagents is expressed on the basis of the amount of protoporphyrin IX formed by the control as $100 \%$ activity.

\begin{tabular}{|c|c|c|c|}
\hline Group & Additives & $\begin{array}{l}(\%) \\
100\end{array}$ & $\begin{array}{c}(\%) \\
80-90\end{array}$ \\
\hline $\mathbf{A}$ & $\left\{\begin{array}{l}\text { Arsenite }(0.04 \mathrm{M}) \\
\text { Arsenite }(0.04 \mathrm{M})+\text { BAL }(0.04 \mathrm{M}) \\
\text { Arsenite }(0.04 \mathrm{M})+\text { BAL }(0.12 \mathrm{M}) \\
\text { BAL }(0.04 \mathrm{M})\end{array}\right.$ & $\begin{array}{r}65 \\
30 \\
30 \\
100\end{array}$ & $\begin{array}{r}100 \\
100 \\
90 \\
96\end{array}$ \\
\hline B & $\left\{\begin{array}{l}\text { CySH }(0.1 \mathrm{mM}) \\
\text { CySH }(1 \mathrm{mM}) \\
\text { CySH }(5 \mathrm{~mm}) \\
\text { CySH }(0.01 \mathrm{M}) \\
\text { CySH }(0.04 \mathrm{M}) \\
\text { CySH }(0.05 \mathrm{M}) \\
\text { GSH }(0.1 \mathrm{mM}) \\
\text { GSH }(0.04 \mathrm{M})\end{array}\right.$ & $\begin{array}{r}110 \\
98 \\
45 \\
28 \\
16 \\
15 \\
109 \\
30\end{array}$ & $\begin{array}{r}89 \\
92 \\
72 \\
95 \\
100 \\
95 \\
90 \\
100\end{array}$ \\
\hline C & $\left\{\begin{array}{l}\text { GSSG }(0.01 \mathrm{M}) \\
\text { Lipoate }(0.01 \mathrm{M}) \\
\text { Iodosobenzoate }(0.04 \mathrm{M})\end{array}\right.$ & $\begin{array}{l}20 \\
10 \\
60\end{array}$ & $\begin{array}{l}77 \\
90 \\
75\end{array}$ \\
\hline D & $\left\{\begin{array}{l}\text { Iodoacetamide* }(0.04 \mathrm{M}) \\
p \text {-Chloromercuribenzoate* }(0 \cdot 1 \mathrm{mM}) \\
N \text {-Ethylmaleimide }(0.04 \mathrm{M}) \\
\text { Fluorodinitrobenzene }(0.04 \mathrm{M}) \\
\text { Ethacrynic acid }(0.04 \mathrm{M}) \\
5,5^{\prime} \text {-Dithiobis-(2-nitrobenzoic acid)* }(1 \mathrm{mM})\end{array}\right.$ & $\begin{array}{r}65 \\
87 \\
64 \\
20 \\
6 \\
90\end{array}$ & $\begin{array}{r}91 \\
100 \\
70 \\
71 \\
28 \\
120\end{array}$ \\
\hline $\mathbf{E}$ & $\left\{\begin{array}{l}\mathrm{Cd}^{2+}(0.02 \mathrm{M}) \\
\mathrm{Pb}^{2+}(0.02 \mathrm{M}) \\
\mathrm{Mg}^{2+}+(5 \mathrm{mM}) \\
\mathrm{Mn}^{2+}(5 \mathrm{mM}) \\
\mathrm{Ca}^{2+}(0 \cdot 01 \mathrm{M}) \\
\mathrm{K}+(0 \cdot 1 \mathrm{M}) \\
\mathrm{Na}^{+}+(0 \cdot 1 \mathrm{M})\end{array}\right.$ & $\begin{array}{r}60 \\
70 \\
106 \\
100 \\
99 \\
100 \\
100\end{array}$ & $\begin{array}{r}100 \\
99 \\
88 \\
86 \\
95 \\
85 \\
85\end{array}$ \\
\hline $\mathbf{F}$ & $\left\{\begin{array}{l}\text { 8-Hydroxyquinoline }(0.04 \mathrm{M}) \\
\text { EDTA (0.01 M) } \\
o \text {-Phenanthroline } \dagger(0.01 \mathrm{M}) \\
\alpha \alpha^{\prime} \text {-Bipyridyl } \dagger(0.01 \mathrm{M}) \\
\mathrm{NaN}_{3} \dagger(5 \mathrm{~mm}) \\
\text { Desferal }(5 \%)\end{array}\right.$ & $\begin{array}{r}150 \\
95 \\
75 \\
74 \\
118 \\
200\end{array}$ & $\begin{array}{r}98 \\
71 \\
86 \\
90 \\
94 \\
100\end{array}$ \\
\hline G & $\left\{\begin{array}{l}\mathrm{KCN}(0.01 \mathrm{M}) \\
\text { Thiourea }(0.02 \mathrm{M}) \\
\mathrm{SO}_{3}{ }^{2-}+(0.02 \mathrm{M})\end{array}\right.$ & $\begin{array}{l}130 \\
102 \\
102\end{array}$ & $\begin{array}{l}92 \\
65 \\
70\end{array}$ \\
\hline $\mathbf{H}$ & $\left\{\begin{array}{l}\text { Galactoflavine } \text { 7-Chloro-6-methylgalactoflavine }(1 \mathrm{mM})(1 \mathrm{mM}) \\
\text { 6.Chloro-7-methylgalactoflavine }(1 \mathrm{mM}) \\
\text { Quinacrine }(5 \mathrm{mM}) \\
\text { Hydroxylamine }(0.01 \mathrm{M})\end{array}\right.$ & $\begin{array}{l}65 \\
65 \\
65 \\
85 \\
98\end{array}$ & $\begin{array}{l}78 \\
76 \\
76 \\
90 \\
98\end{array}$ \\
\hline $\mathbf{I}$ & $\left\{\begin{array}{l}\text { Dinitrophenol (1 mM) } \\
\text { Pyridoxal phosphate }(0.1 \mathrm{mM}) \\
\text { Pyridoxal phosphate }(5 \mathrm{mM}) \\
\text { Deoxypyridoxine }(0 \cdot 1 \mathrm{mM}) \\
\text { Deoxypyridoxine }(5 \mathrm{mM}) \\
\text { Pyridoxal phosphate }(0.1 \mathrm{mM})+\text { deoxypyridoxine }(0 \cdot 1 \mathrm{mM}) \\
\text { Pyridoxal phosphate }(5 \mathrm{mM})+\text { deoxypyridoxine }(5 \mathrm{mM})\end{array}\right.$ & $\begin{array}{r}100 \\
99 \\
98 \\
98 \\
96 \\
97 \\
95\end{array}$ & $\begin{array}{l}80 \\
85 \\
84 \\
88 \\
84 \\
85\end{array}$ \\
\hline
\end{tabular}

Porphyrin

Activity

$(\%)$

$65 \quad 100$

$30 \quad 100$

$30-90$

$110 \quad 89$

92

95

100

95

90

77

70

71

86

85

86

100

70

78

90

85

84

83

Bioch. 1965, 97 
Table 2 (continued).

\begin{tabular}{|c|c|c|c|}
\hline Group & Additives & $\begin{array}{c}\text { Activity } \\
(\%)\end{array}$ & $\begin{array}{c}\text { Porphyrin } \\
\text { recovery } \\
(\%)\end{array}$ \\
\hline \multirow{10}{*}{$\mathbf{J}$} & {$[\beta$-Hydroxybutyric acid $(0.04 \mathrm{M})$} & 100 & 74 \\
\hline & Malic acid $(0.04 \mathrm{M})$ & 100 & 71 \\
\hline & Lactic acid $(0.04 \mathrm{M})$ & 65 & 91 \\
\hline & Pyruvic acid (0.04M) & 130 & 91 \\
\hline & Succinic acid $(0.04 M)$ & 99 & 98 \\
\hline & Malonic acid $(0.04 \mathrm{M})$ & 89 & 70 \\
\hline & Fumaric acid $(0.04 \mathrm{~m})$ & 100 & 97 \\
\hline & Maleic acid $(0.04 \mathrm{M})$ & 65 & 70 \\
\hline & trans-Cinnamic acid $(0.04 \mathrm{M})$ & 120 & 80 \\
\hline & cis-Cinnamic acid $(0.04 \mathrm{M})$ & 125 & 85 \\
\hline
\end{tabular}

of arsenite (about $0.1 \mathrm{~mm}$ ) than the concentrations necessary to show significant inhibition with monothiol enzymes (1-100mm). Thus its action on CPGase could be interpreted as indicating the presence of monothiol rather than vicinal dithiol groups in this system. When attempts were made to reverse the inhibition by the addition of an equivalent concentration or excess of BAL to the arsenite-treated system, inhibition was not overcome but increased, although BAL alone was not inhibitory. Pre-mixed arsenite and BAL brought about the same degree of inhibition as did sequential addition.

The effects of BAL-arsenite could be duplicated if BAL was replaced by lipoate, or the monothiols CySH and GSH, provided that arsenite was first preincubated for $20 \mathrm{~min}$. with the system before addition of the two last-named compounds.

The action of GSH or CySH alone was studied (Table 2, group B) in a wide range of concentrations. The lowest concentration tested produced a slight stimulation, possibly due to the removal of inhibitory trace metals, then no action was evident up to $5 \mathrm{mM}$, at which the enzyme was noticeably inhibited.

To obtain further information about the presence of thiol groups some oxidizing reagents were examined (Table 2, group C). Oxidized glutathione and lipoate at $0.01 \mathrm{M}$ produced a marked inhibition and iodosobenzoate at $0.04 \mathrm{M}$ inhibited CPGase by $40 \%$.

To control that the inhibitory effect was not actually exerted on the substrate, CPG III $(0.5 \mathrm{ml}$. of $0.015 \mathrm{~mm}$ ) was incubated with some of the reagents at $\mathrm{pH} \mathrm{7.4,} \mathrm{at} \mathrm{room} \mathrm{temperature} \mathrm{in} \mathrm{the} \mathrm{dark,}$ in evacuated Thunberg tubes, the final volume being 2ml. CPG III was reasonably stable for at least $24 \mathrm{hr}$. in the presence of GSSG, hydrogen peroxide, lipoate and iodosobenzoate; no porphyrin fluorescence was observed after $24 \mathrm{hr}$. and the recovery of coproporphyrin after reoxidation was between 95 and $100 \%$; chromatography of the porphyrin present after such incubation revealed only coproporphyrin III.

Alkylating and mercaptide-forming thiol reagents (Table 2, group D). The effect of preincubation with iodoacetamide was examined, and similar behaviour was obtained whether or not iodoacetamide was preincubated for different times with the enzyme; 5,5'-dithiobis-(2-nitrobenzoic acid) at 0.04 M only slightly inhibited the purified enzyme. $p$ Chloromercuribenzoate at $0.1 \mathrm{~mm}$ showed some degree of inhibition. $N$-Ethylmaleimide at $0.04 \mathrm{M}$ inhibited $36 \%$ and fluorodinitrobenzene also markedly decreased CPGase activity. Ethacrynic acid, a product binding with thiol groups of proteins (Komorn \& Cafruny, 1964), was tested but the low porphyrin recovery signified that porphyrin had been destroyed and these results were therefore inconclusive.

Metals and chelating agents (Table 2, group E). Only $\mathrm{Cd}^{2+}$ and $\mathrm{Pb}^{2+}$ at $0.02 \mathrm{M}$ were found to inhibit, between $30 \%$ and $40 \%$; enzyme activity was not affected by $\mathrm{Mg}^{2+}, \mathrm{Mn}^{2+}, \mathrm{Ca}^{2+}, \mathrm{K}^{+}$or $\mathrm{Na}^{+}$. To obtain further information about the possible presence of any metal, some metal chelators were studied (Table 2, group F). The only reagents found to inhibit were $o$-phenanthroline and $\alpha \alpha^{\prime}$ bipyridyl, but this inhibition was removed by dialysis. The other chelators tested did not inhibit CPGase; some of them stimulated. On addition of $\alpha \alpha^{\prime}$-bipyridyl, $o$-phenanthroline or 8-hydroxyquinoline a red colour developed, suggestive of the formation of an iron complex, but this phenomenon was not further investigated.

Cyanide, thiourea and sulphite (Table 2, group G). None of these compounds inhibited CPGase. They are known to react with disulphide bonds of certain proteins; therefore on the basis of these and other results it can be deduced that the enzyme does not specifically require disulphide bonds for its activity.

Flavine analogues and hydroxylamine (Table 2, group $H$ ). Compounds related to flavine showed a 
certain degree of inhibition, whereas hydroxylamine did not affect the enzymic activity.

Dinitrophenol, pyridoxal phosphate and deoxypyridoxine (Table 2, group $I$ ). None of these compounds had any effect on CPGase.

Carboxylic acids (Table 2, group $J$ ). The activity of the enzyme was not affected by the presence of $\beta$-hydroxybutyric acid, malic acid, succinic acid or fumaric acid. Pyruvic acid produced a certain increase in activity, as did both trans- and ciscinnamic acid; malonic acid inhibited approx. 10\% and both lactic acid and maleic acid inhibited to the extent of $35 \%$.

\section{DISCUSSION}

The activity of CPGase prepared from rat-liver mitochondria was not affected by prolonged dialysis, suggesting that no diffusible cofactors are necessary for its action. All other attempts to demonstrate a requirement for a cofactor were unsuccessful.

Final purification by chromatography on Sephadex G-200 yielded an apparently homogeneous colourless protein with 58-fold enhanced CPGase activity. No indication was obtained that more than one enzyme is concerned in the conversion of CPG III into protoporphyrin IX. Some of the workers who have previously studied the mechanism of the oxidative decarboxylation of CPG III concluded that the reaction does not involve essential thiol groups, but evidence is presented in this paper to show that the enzyme system responsible for the transformation may in fact require thiol groups for its activity.

Arsenite inhibited the reaction when used at high concentrations, of the order of those required to inhibit monothiol enzymes, although inhibition did not occur at the lower concentrations known usually to be effective inhibitors of vicinal dithiol systems. BAL was not inhibitory itself but enhanced the inhibition due to arsenite. When arsenite is mixed in solution with a dithiol compound such as BAL, a cyclic thioarsenite is formed; so one explanation could be that arsenite by itself cannot easily reach a functional site in the enzyme system, but complexformation with BAL allows it to be transported readily to an enzyme site which might be a thiol group. Thus BAL would act as a simple carrier of arsenite either by virtue of the lower charge on the complex or of its increased lipid solubility. The thioarsenite complex may act by a mechanism different from thiol binding, attacking some other type of functional group on the enzyme. In any case, excess of BAL would not be expected to have any effect since the concentration of the complex would not be decreased by the presence of excess of BAL.
The possibility of the existence of monothiol functional groups is supported by experiments with some thiol-oxidizing reagents, which were also found to inhibit the reaction. It has been demonstrated that the action of these reagents is not due to increase of autoxidation or to the destruction of the substrate. The reaction was also inhibited by several alkylating and mercaptide-forming thiol reagents, and this adds further support for the presence of monothiol groups. Porra \& Falk (1964), studying the effect of oxygen pressure on the conversion of CPG III into protoporphyrin IX, found that the reaction reaches maximum activity at about $20 \%$ of oxygen but is inhibited at concentrations greater than $20 \%$. They explained this inhibition as being due either to autoxidation of the substrate or to inhibition of the enzyme by high oxygen pressure, but it could also be due to oxidation of thiol groups of CPGase.

Among several metals tested, $\mathrm{Cd}^{2+}$ and $\mathrm{Pb}^{2+}$ inhibited CPGase; this could also be due to combination between the metal and some thiol groups of the enzymes.

The presence of monothiol groups in our enzymic system is therefore visualized, although a mechanism for their participation cannot yet be postulated. They could stabilize the enzyme-substrate complex through hydrogen bonding, or they might, perhaps, be indispensable to the enzyme itself by conferring a definite structural arrangement necessary for its activity.

As stated above, the existence of dithiol groups appears to be excluded since in general inhibition of dithiol systems occurs at much lower concentrations than those found to be necessary here. In addition, cyanide, sulphite and thiourea, reagents known to cleave disulphide bonds, did not inhibit.

The inhibitory action of the monothiols CySH and GSH may be due either to competition with thiol groups in the enzyme for the substrate, or an intermediate derived from it, or to direct binding with this intermediate.

Morgan \& Friedman $(1938 a, b)$ showed that GSH, $\mathrm{CySH}$ and maleic acid can form addition compounds by the reaction of their thiol group with a double bond and Rimington \& Tooth (1961) suggested that the oxidative decarboxylation of CPG III to protoporphyrin IX may proceed via diacrylicdeuteroporphyrinogen. As shown by Sano \& Granick (1961) and confirmed in this Laboratory, trans-2,4-diacrylicdeuteroporphyrin was not acted upon by CPGase, but, assuming that the real intermediate is the cis isomer, GSH or CySH could add across the ethylenic linkages, so blocking further reaction; alternatively isomerization to the trans form might result.

With the exception of $o$-phenanthroline and $\alpha \alpha^{\prime}$ bipyridyl, which inhibited the reaction (although 
inhibition was removed by dialysis), the addition of metal chelators did not inhibit but rather enhanced CPGase activity; the observed formation of a red colour on addition of $\alpha \alpha^{\prime}$-bipyridyl, $o$-phenanthroline or 8-hydroxyquinoline must nevertheless be noted. The activity of the enzyme was stimulated by some metal chelators and low concentrations of reduced glutathione and cysteine. This stimulation is possibly due to the removal or displacement of other ineffective metal ions, or combination with metals which could catalyse autoxidation of the substrate or oxidizable groups in the enzyme, such as thiol residues.

Therefore present evidence indicates that CPGase activity does not involve any metal ion, but the possibility remains that a metal could be so tightly bound to the protein that it is impossible either to release it from the enzyme or to inhibit the reaction by the use of metal chelators.

All attempts to detect a prosthetic group, e.g. a flavine, failed, but by the addition of some flavine analogues CPGase was slightly inhibited. However, these results are inconclusive.

Dinitrophenol did not inhibit. Granick \& Mauzerall (1958) have reported that ATP did not stimulate their enzyme.

Pyridoxal phosphate and its analogue deoxypyridoxine did not affect enzymic activity, suggesting that the reaction does not involve pyridoxal phosphate, a cofactor sometimes required in decarboxylations. The absence of any haem group is suggested by the fact that cyanide did not inhibit the reaction. The enzyme is inhibited by anaerobiosis. Oxygen functioning as a terminal electron acceptor is essential for the conversion of CPG III into protoporphyrin IX. No oxidant other than oxygen was found to be utilized by the enzyme. It is unlikely that a functional mitochondrial electrontransport chain is necessary for the enzyme activity.

The action of various carboxylic acids was examined. Fumaric acid did not affect CPGase activity but maleic acid inhibited by $35 \%$. It has been suggested that the oxidative decarboxylation of CPG III could proceed via an acrylic acid and subsequent decarboxylation (Rimington \& Tooth, 1961; Sano \& Granick, 1961). As the trans isomer of 2,4-diacrylicdeuteroporphyrin is not acted upon by CPGase (Sano \& Granick, 1961) it is possible that the real intermediate is the cis isomer; this is supported by the fact that fumaric acid, the trans isomer of 1,2-ethylenedicarboxylic acid, did not inhibit the reaction whereas maleic acid, the cis isomer, did.
A. M. C. B. thanks the Consejo Nacional de Investigaciones Cientificas y Técnicas, Argentina, for the award of a postgraduate research fellowship. This work forms part of a Thesis submitted for the degree of $\mathrm{Ph} . \mathrm{D}$. to the University of London by A. M. C. B. We thank Professor R. H. Thomson, University of Aberdeen, for a gift of cis-cinnamic acid.

\section{REFERENCES}

Andrews, P. (1964). Biochem. J. 91, 222.

Bodman, J. (1960). In Chromatographic and Electrophoretic Techniques, vol. 2, p. 129. Ed. by Smith, I. London: William Heinemann Ltd.; New York: Interscience Publishers Inc.

Bogorad, L. (1960). Symp. comparative Biochemistry, vol. 1, p. 227. Ed. by Allen, M. B. New York and London: Academic Press Inc.

Bogorad, L. \& Marks, G. S. (1960). J. biol. Chem. 235, 2127. Cornford, P. A. D. (1964). Biochem. J. 91, 64.

Dixon, M. (1953). Biochem. J. 55, 457.

Dresel, E. I. B. \& Falk, J. E. (1954). Biochem. J. 56, 156. Eriksen, L. (1958). Scand. J. clin. Lab. Invest. 10, 319.

Falk, J. E. \& Benson, A. (1953). Biochem. J. 55, 101.

Falk, J. E., Dresel, E. I. B. \& Rimington, C. (1953). Nature, Lond., 172, 292.

Granick, S. \& Levere, R. D. (1964). Progr. Hemat. 4, 1. Granick, S. \& Mauzerall, D. (1958). Fed. Proc. 17, 233.

Gray, C. H. \& Holt, L. B. (1948). Biochem. J. 43, 191.

Hogeboom, G. H. (1955). In Methods in Enzymology, vol. 1, p. 16. Ed. by Colowick, S. P. \& Kaplan, N. O. New York: Academic Press Inc.

Keilin, D. \& Hartree, E. F. (1951). Biochem. J. 49, 88.

Komorn, R. M. \& Cafruny, E. J. (1964). Science, 148, 133.

Lowry, O. H., Rosebrough, N. J., Farr, A. L. \& Randall, R. J. (1951). J. biol. Chem. 193, 265.

Mauzerall, D. \& Granick, S. (1958). J. biol. Chem. 232, 1141. Morgan, E. J. \& Friedman, E. (1938a). Biochem. J. 32, 723. Morgan, E. J. \& Friedman, E. (1938b). Biochem. J. 32, 862. Morton, R. K. (1961). Nature, Lond., 192, 727.

Morton, R. K., Armstrong, J. McD. \& Appleby, C. A. (1961). In Haematin Enzymes, p. 501. Ed. by Falk, J. E., Lemberg, R. \& Morton, R. K. London: Pergamon Press Ltd. Porra, R. J. \& Falk, J. E. (1961). Biochem. biophys. Res. Commun. 5, 179.

Porra, R. J. \& Falk, J. E. (1964). Biochem. J. 90, 69.

Rimington, C. \& Sveinsson, S. L. (1950). Scand. J. clin. Lab. Invest. 2, 209.

Rimington, C. \& Tooth, B. E. (1961). J. Biochem., Tokyo, 49, 456.

Sano, S. (1958). Acta haemat. jap. 21 (2), 337.

Sano, S. \& Granick, S. (1961). J. biol. Chem. 236, 1173. Seaman, G. \& Naschke, H. (1955). J. biol. Chem. 213, 705.

Sparatore, F. \& Mauzerall, D. (1960). J. org. Chem. 25, 1073.

Wildy, J., Nizet, A. \& Benson, A. (1961). Biochim. biophys. Acta, 54, 414. 